\title{
New Modified Method for Determination of Nitric oxide Synthase Activity in Plasma of Vitiligo Patients
}

\author{
JWAN ABDULMOHSIN ZAINULABDEEN and AYMEN ABDULSATTAR ALKINANI* \\ Department of Chemistry, College of Sciences, University of Baghdad, Baghdad, Iraq. \\ ${ }^{\star}$ Corresponding author E-mail: Aymenalkinani90@gmail.com
} http://dx.doi.org/10.13005/ojc/340536

(Received: July 03, 2018; Accepted: September 10, 2018)

\begin{abstract}
Vitiligo is a non-contagious skin disorder that characterized by depigmentation of skin due to melanocyte impairment which may be caused to increase levels of free radicals (such as superoxide and nitric oxide) that causing an increase in oxidative stress. The purpose of this study was measured by the activity of oxide synthase (NOS) by our modified method and nitric oxide concentration in plasma of vitiligo patients. The activity of nitric oxide synthase was determined via a modified method by coupling two methods; the first method was based on converting L-arginine to L-citrulline and nitric oxide and the second was used to measure the concentration of nitric oxide. This modified method was applied to patients with vitiligo disease and healthy individuals who matched in age and gender with patients. The condition of this modified method was optimized and the results revealed the following: the activity of NOS was higher in a solution that contains: Tris buffer (50mM), arginine $(100 \mathrm{mM})$, calcium chloride $(20 \mathrm{mM})$, and NADPH $(5 \mathrm{mM})$ during $30 \mathrm{~min}$. meanwhile the precision of this method was 2.03. In the current study, the results show that the levels of NOS activity and nitric oxide were affected by the disease in which both parameters appeared highly significant increases in vitiligo patients ( $p=0.000$ and 0.002 respectively) in comparison with the healthy individuals. Results of the experiments proved that it is possible to depend on the modified method to measure the activity of nitric oxide synthase (NOS). Also, the increased levels of NOS activity and nitric oxide concentration in vitiligo patients support the autocytotoxic hypothesis which suggests that oxidative stress may have a role in melanocyte impairment.
\end{abstract}

Keyword: Nitric oxide synthase, Nitric oxide, Vitiligo and Oxidative stress.

INTRODUCTION

Vitiligo is a skin pigmentation disorder and non-contagious disease, which is characterized by progressive skin depigmentation due to disorder in melanocytes function. With the prevalence of $1-2 \%$, this disease represents a cause of stigmatization and effect on the lifestyle of the vitiligo patients ${ }^{1}$.
This disease can be classified into the two major form segmental (which is the most prevalent form) and non-segmental vitiligo ${ }^{2}$. The others subsets of this disease have been reported which including localized, generalized and universal types ${ }^{2}$.

The pathogenesis of this disease is still unknown so far; various hypotheses have been

This is an Open Access article licensed under a Creative Commons Attribution-Non Commercial-Share Alike 4.0 International License (https://creativecommons.org/licenses/by-nc-sa/4.0/), which permits unrestricted Non Commercial use, distribution and reproduction in any medium, provided the original work is properly cited. 
proposed. They include the genetic hypothesis ${ }^{3}$, the autoimmune hypothesis ${ }^{4}$, and the neural hypothesis ${ }^{5}$. Finally, the autocytotoxic hypothesis which suggests that oxidative stress may have a role in melanocyte impairment ${ }^{6,7}$. The increase in oxidative stress may be due to increased ROS that results from mitochondrial impairment ${ }^{8}$ and a reduced antioxidant level ${ }^{9}$ shied the light on the concept of a possible systemic oxidative stress in vitiligo.

The increased in the oxidative stress causes DNA damage, lipid and protein peroxidation ${ }^{10,11}$ such as inhibition of some essential enzymes like tyrosinase ${ }^{12}$.

Nitric oxide (NO) is a unique messenger molecule, which has different molecular targets. NO has a regulatory function such as neurotransmission ${ }^{13}$ or vascular tone ${ }^{14}$, regulates gene transcription ${ }^{15}$ and mRNA translation ${ }^{16}$ and produces post-translational modifications of proteins ${ }^{17}$. This messenger molecule can be inactivation by reaction with superoxide anion $\left(\mathrm{O}_{2}-\cdot\right)$ to form the potent oxidant peroxynitrite (ONOO) ${ }^{18}$. ONOO- compound can cause oxidative damage, nitration, and S-nitrosylation of biomolecules including proteins, lipids, and DNA ${ }^{19}$, 20. In mammals, NO produce from three distinct isoforms of NOS; neuronal NOS (nNOS), inducible NOS (iNOS) and endothelial NOS (eNOS) have been identified. These isoforms are products by different genes, with different localization, regulation, catalytic properties and inhibitor sensitivity, and with 51-57\% homology between the human isoforms ${ }^{21}$.

Numerous methods have been reported to assess NOS activity, and the most popular of these involves the determination of NOS activity by used NO to converted of oxyhemoglobin to methemoglobin and monitoring the absorption difference between the wavelengths 401 and $421 \mathrm{~nm}$ or at just $401 \mathrm{~nm}^{22}$ or by measured radiochemical compound such as $L-\left[{ }^{14} \mathrm{C}\right]$ arginine to $\mathrm{L}-\left[{ }^{14} \mathrm{C}\right]$ citrulline ${ }^{23}$. The aims of the present study were to the determination of nitric oxide synthase activity by using the new modified method and nitric oxide concertation in heparinized plasma of vitiligo and evaluate the role of these parameters in the pathogenesis of vitiligo.

\section{MATERIALS AND METHODS}

\section{Sample preparation}

Fasting whole blood was collected (5.0ml) from the patients and healthy individual, in a heparin tube at room temperature. Then the tube was centrifuged $(2000 \times \mathrm{g})$ for $10 \mathrm{~min}$. the clear plasma was used for determining the activity of nitric oxide synthase and the concentration of nitric oxide immediately.

\section{Exclusion criteria}

Pregnancy, diabetic, anemia, lactation, history of cutaneous photosensitivity, eye cataract or skin, cancer, dermatitis, psoriasis, taking a potent antioxidant, history of alcohol intake, smokers were excluded. This study protocol was approved by the Ethics Committee of the College of the Science/ University of Baghdad.

\section{Determination of nitric oxide synthase activity}

The activity of nitric oxide synthase was determined via a modified method by coupling two methods; the first method was based on converting $\mathrm{L}$-arginine to L-citrulline and nitric oxide as shown in Table 1.

Table 1: Assay conditions of nitric oxide synthase activity

\begin{tabular}{lcc}
\hline Components & Concentration & Volume \\
\hline Tris buffer, pH 7.4 & $50 \mathrm{mM}$ & $90 \mu \mathrm{L}$ \\
$\mathrm{CaCl}_{2}$ & $20 \mathrm{mM}$ & $50 \mu \mathrm{L}$ \\
$\mathrm{NADPH}$ & $5 \mathrm{mM}$ & $80 \mu \mathrm{L}$ \\
Arginine & $100 \mathrm{mM}$ & $30 \mu \mathrm{L}$ \\
Plasma volume & & $100 \mu \mathrm{L}$ \\
\hline
\end{tabular}

The test was incubated at 37 for 30 minutes (control contain all reagent except plasma add after incubation)

The half-life of NO in biological fluids reaches to the seconds, therefore is determined according to its stable oxidation end products nitrite $\left(\mathrm{NO}_{2}-\right)$, which then measured according to Cortas et al., ${ }^{24}$ (with some modification: using $400 \mu \mathrm{L}$ of ZnSO4 $(75 \mathrm{mmol} / \mathrm{L})$ instated $40 \mu \mathrm{L}$ and $500 \mu \mathrm{L}$ of $\mathrm{NaOH}(55 \mathrm{mmol} / \mathrm{L})$ instated $50 \mu \mathrm{L}$. The standard curve for nitric oxide was shown in Figure 1. 

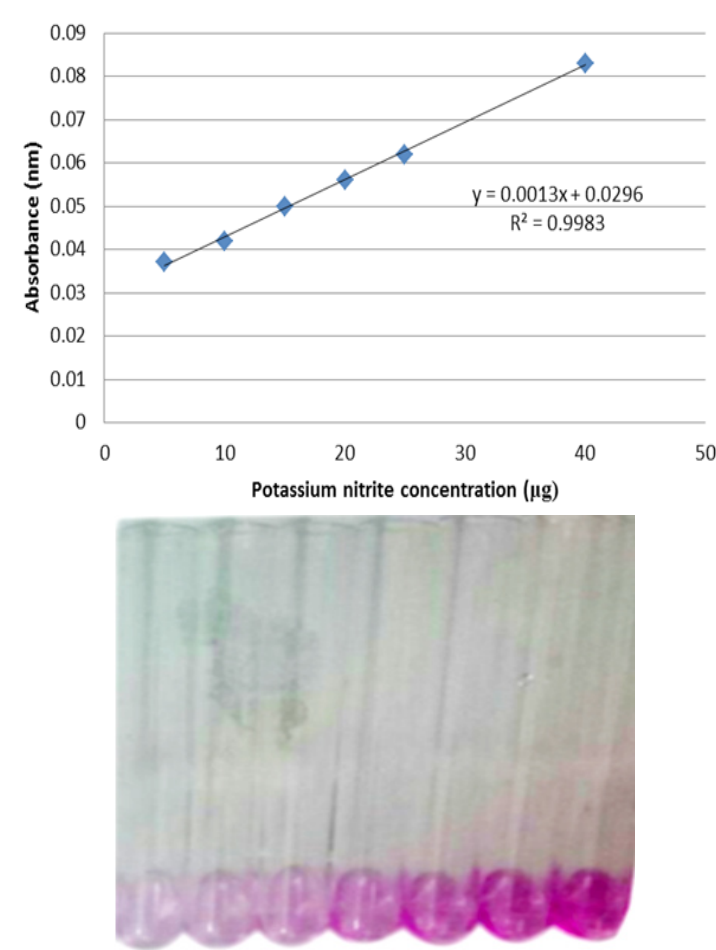

Fig. 1. Standard curve for estimated nitric oxide concentration to measurement nitric oxide synthase activity

\section{Expressing the oxide synthase activity}

The amount of nitrite formed by $100 \mu \mathrm{L}$ of plasma after 30-min. incubation can be expressed in units corresponding to $\mu$ mole of nitrite/min per $1 \mathrm{~L}$ of plasma.

NOS activity $=\mu \mathrm{g}$ of nitrite (test - control) $)^{\star} 7.24$

The factor $7.24=10 * 1000 * 1 / 46 * 1 / 30$

Where $10 * 1000$ is the conversion from 0.1 $\mathrm{ml}$ plasma to $1000 \mathrm{ml}, 46$ is the molecular weight of nitrite, 30 is the incubation time in a minute.

\section{Effect of arginine Concentration}

Nitric oxide synthase enzymatic reaction was done under optimum reaction condition using series concentrations of arginine as a substrate [10, $20,50,70,90,100,130$ and 150 mmole/L]. The curve was plotted between each substrate concentrations and the enzyme activity in order to measure the optimum substrate concentration for each enzyme activity.

\section{Effect of the buffer concentration}

The enzymatic reaction was done by using different tris buffer concentrations [10, 20,30,40, $50,60,70$ and $80 \mathrm{mmole} / \mathrm{L}]$. The optimum buffer concentration was calculated by plotting the curve between the enzyme activities versus the buffer concentrations.

\section{Effect of the calcium chloride concentration}

Nitric oxide synthase enzymatic reaction was done under optimum reaction state using series calcium chloride concentration $[5,10,15,20,25$, 30 and $35 \mathrm{mmole} / \mathrm{L}]$. The optimum concentration of calcium chloride was determined by plotting the curve between the enzyme activities versus different calcium chloride concentration.

\section{Effect of NADPH concentration}

The optimum concentration of NADPH for the enzymatic reaction was measured by using a different concentration of NADPH [0.5, 1, 2, 3, 4, $5,6$ and $7 \mathrm{mmole} / \mathrm{L}]$. The optimum concentration of NADPH was estimated by plotting the relationship between the enzyme activities versus different NADPH concentration.

\section{Effect of sample volume}

The enzymatic reaction was carried out with different plasma volume $[10,20,40,60,80,100,120$ and $150 \mu \mathrm{L}]$. The optimum volume was measured by scheming the relationship between the enzyme activities on Y-axis and different volumes of plasma on the $\mathrm{X}$-axis.

\section{Effect of incubation time}

The effect of incubation time was determined at $37^{\circ} \mathrm{C}$ for $[5,10,15,20,25,30,35$, and 40 minutes]. The optimum incubation time was estimated by plotting the correlation between the enzyme activities versus the incubation time values.

\section{Determination of nitric oxide concentration}

Nitric oxide concentration in plasma was measured according to Cortas etal24 which depend on the reaction between its stable oxidation end-products of nitrite/nitrate and Griess reagent.

\section{Statistical analysis}

The data analysis was done by using a statistics software package (SPSS v.20 for Windows). All groups showed normal distribution so that parametric statistical methods were used to analysis the data. Independent $z$-test was used for differences between groups, and the P-value was 
considered significant if it is $<0.05$. Results are presented as means \pm SD.

\section{RESULT}

A total of 95 of patients with vitiligo and 40 aged and gender-matched controls were included in the current study. Our modified method of determination of the activity of NOS has riled on combine two methods. The first method was based on converting L-arginine to L-citrulline and nitric oxide, the last one has a short life (few seconds) was rapidly produced nitrite and nitrate. Nitrate is more stable from nitrite, in vitro nitrate stable for $24 \mathrm{~h}$ while nitrite stable for 2 hours. The second method which depends on Mani et al to determined nitric oxide concentration by reducing nitrate to nitrite using activated cadmium granules. In the last step, nitrite was reacted with Grease reagent to generate purple azo dye that can be measured by spectrophotometric at $540 \mathrm{~nm}^{24}$ (Figure 2).

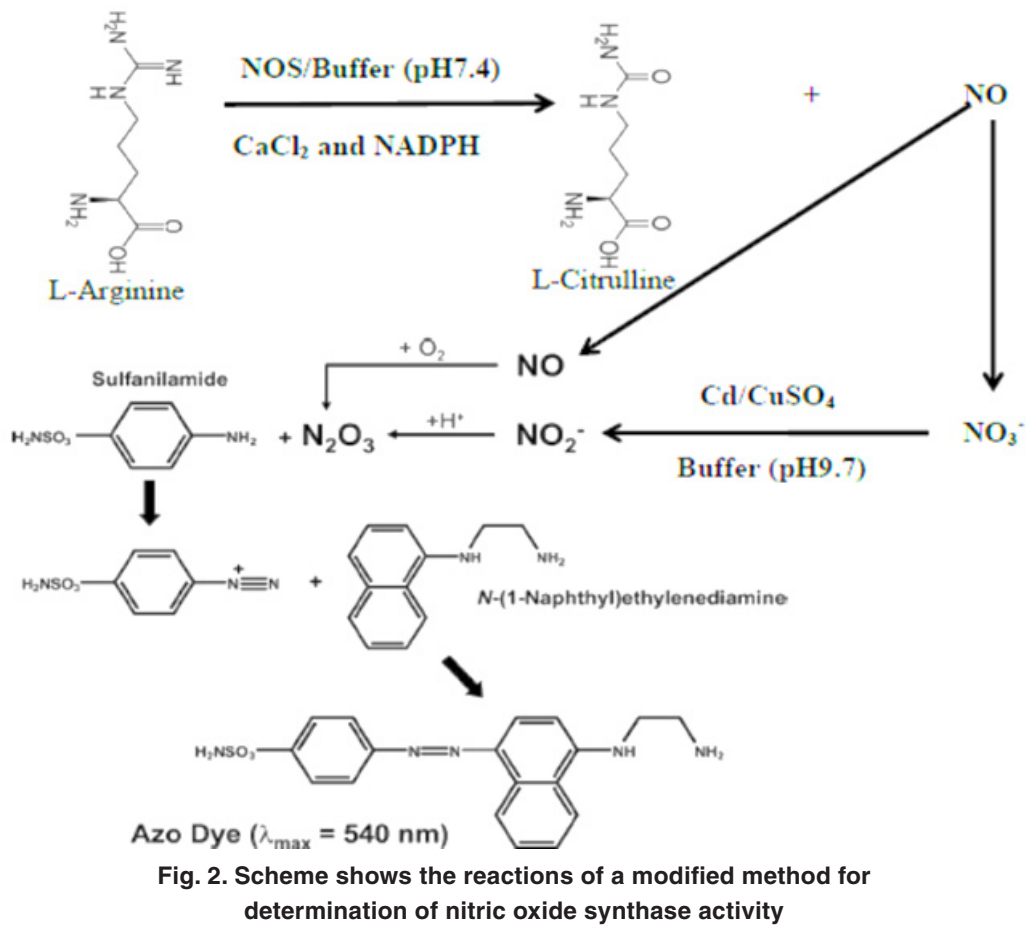

The activity of the NOS was measured in the presence of different concentrations of arginine as a substrate. It was found that the maximum activity of the enzyme was obtained by using (100 mmol/L) of arginine concentration (Fig. 3A). The buffer concentration was the effect on NOS activity, and the optimum activity of enzymatic reaction was obtained at $(50 \mathrm{mmol} / \mathrm{L})$ (Fig. 3B). The result in (Fig. 3C) showing the maximum activity of NOS at [20 $\mathrm{mmol} / \mathrm{L}$ ] of cofactor calcium chloride concentration, while (Fig. 3D) illustrated the effect of NADPH concentration on the activity of enzymatic reaction and the result showed the maximum activity was at $[5 \mathrm{mmol} / \mathrm{L}]$. The Fig. $3 \mathrm{E}$ and $3 \mathrm{~F}$ showing the maximum activity of NOS in different incubation time and volume of plasma and the final result was $30 \mathrm{~min}$. and $100 \mu \mathrm{L}$ of plasma respectively.

Table 2: Mean of nitric oxide activity and nitric oxide concentration in plasma samples of the studied groups

\begin{tabular}{lccc}
\hline Group Sample & Nitric oxide & Nitric oxide \\
number synthase activity & concentration $(\mu \mathrm{g})$ \\
& & $(\mathrm{U} / \mathrm{L})$ Mean \pm SD & Mean \pm SD \\
\hline Control & 40 & $46.45 \pm 14.22$ & $45.21 \pm 6.95$ \\
Vitiligo & 65 & $118.28 \pm 37.95$ & $66.71 \pm 24.86$ \\
patients & & & \\
P value & 0.000 & 0.002 \\
\hline
\end{tabular}

The activity of NOS was measured in both patients of vitiligo and healthy individual. It is clear from the result in the Table (2) the NOS activity has a highly significant increase was noticed in this between healthy and vitiligo patient $(P=0.000)$. The 
concentration of nitric oxide was measured in plasma samples (Table 2), the obtained results reflect the

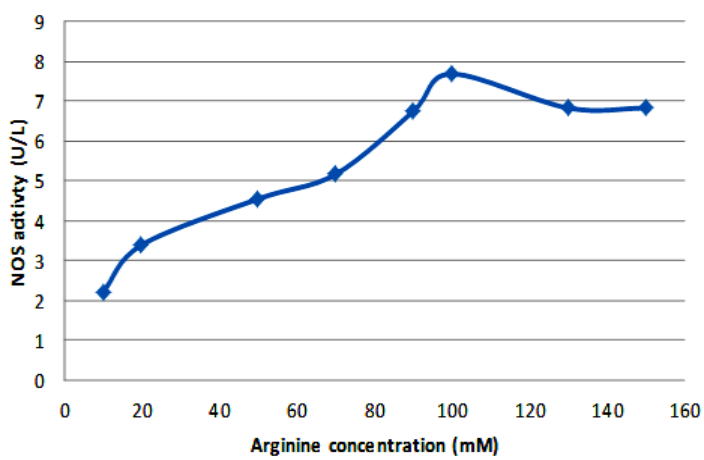

(a)

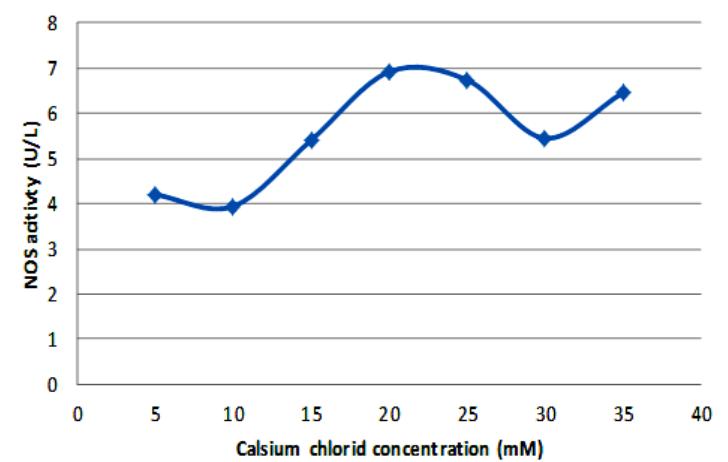

(c)

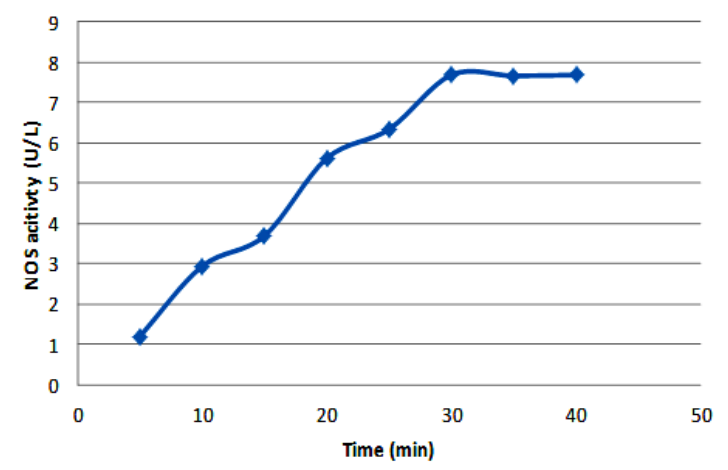

(e) presence of a significant increase $(p=0.002)$ in nitric oxide concentration.

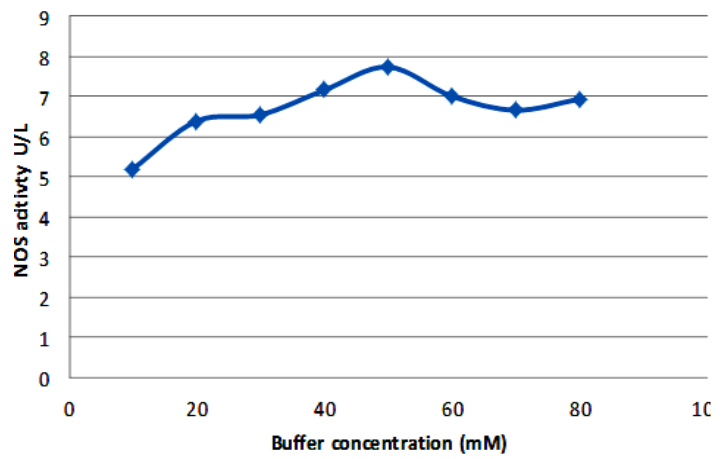

(b)

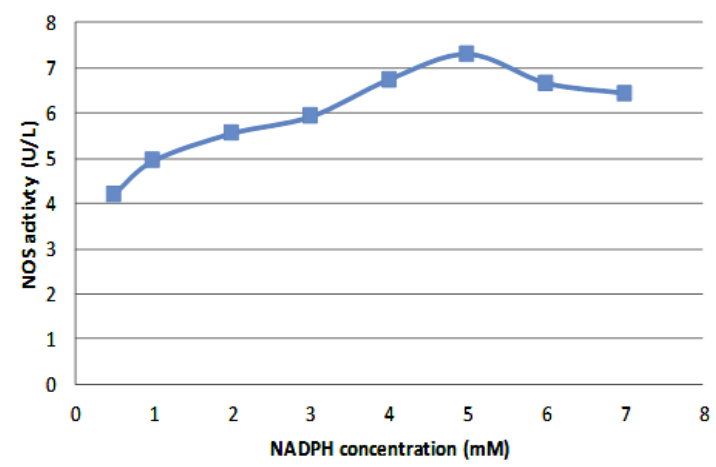

(d)

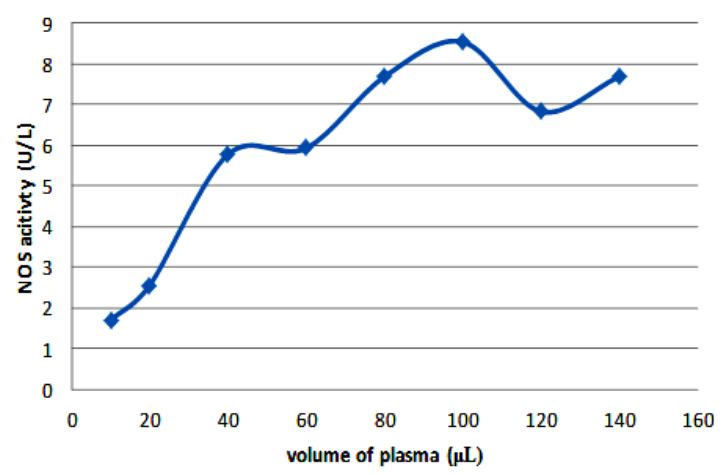

(f)

Fig. 2. The optimizing condition of NOS activity, where: A: for arginine concentration (mM), B: for buffer concentration (mM), C: for calcium chloride concentration (mM), D: for NADPH concentration (mM), , E: for time (minute) and F: for volume of plasma $(\mu \mathrm{l})$

\section{DISCUSSION}

Different methods that used to the estimation of NOS activity which depend either on the radiochemical compound such as converted $\mathrm{L}-\left[{ }^{14} \mathrm{C}\right]$ arginine to $\mathrm{L}\left[{ }^{14} \mathrm{C}\right]$ citrulline ${ }^{23}$ or based on measurement of conversion of oxyhemoglobin to Methemoglobin by $\mathrm{NO}^{22}$. In the present method, the $\mathrm{L}$-arginine acted as a substrate that consumed by an enzymatic reaction which catalyzed by NOS enzyme to produce L-citrulline and $\mathrm{NO}^{25}$. Subsequently, $\mathrm{NO}$ molecule has a short life which converts to nitrite and the last convert to nitrate. Nitrate reduced again by $\mathrm{Cd} / \mathrm{CuSO}_{4}$ to produced nitrite that reacted with grease reagent to generate purple azo dye that can be measured by spectrophotometric at $540 \mathrm{~nm}^{24}$ as shown in Fig. (1). NOS activity is directly proportional to the absorbance of purple azo dye that formed by nitrite.

The accuracy of our modified method was assessed by determined the precision of NOS activity which was less than 2.03 . 
The present method has many advantages over previous methods for determining NOS activities in the plasma samples. Among these, reduce exposure to radiochemical compound ${ }^{23}$ and not need for purification and desalting ${ }^{22}$. Also, compared with many previously developed methods, the material of the present method is inexpensive, does not require a lot of preparation. The disadvantage of our modified method was at the time that required for analysis.

The melanocytes cells of vitiligo patients are the theatre where the balance loss of reductionoxidation because increased free radical level or toxic metabolites, or because of a disorder in antioxidant production.

In the present study, it was observed that the NOS activity and nitric oxide concentration in the vitiligo patients group significantly increased than in the corresponding healthy control group (Table 1). The result was agreement with many reports that proved increased in the activity of NOS and NO concentration in vitiligo patient ${ }^{27-30}$. In the inflammation conditions, the activity NOS increased and this contributes to the cytotoxic action of inflammatory cellular infiltrates around normal human melanocytes ${ }^{31}$ and the increase in the NOS activity lead to increase in the NO production from amino acid L-arginine ${ }^{21}$.

In vitro study, Melanocytes cells that isolated from normal lesion pigmented skin of vitiligo patients exhibit a highly significant increased to various oxidative stress ( chemical and physical) ${ }^{32}$ which lead imbalance of intracellular antioxidants ${ }^{33,34}$.

The effect of increased production of $\mathrm{NO}$ on the melanocytes was caused to reduce the ability of these cells to attach to the extracellular matrix and may contribute to depigmentation ${ }^{35}$. Furthermore, NO may be lead to auto-destruction of normal human melanocytes ${ }^{36}$. Also, many reports suggested that a high concentration of NO could induce apoptotic cell death in neuronal cells, and thus cause neuronal injury by the interaction with excitatory amino acid receptors $^{37}$, the depletion of cellular NAD ${ }^{38}$, and the activation of caspases ${ }^{39}$ are involved in the cascade of events leading to NO-induced apoptosis.

In animal study, Li et al., ${ }^{40}$ prove that increased in $\mathrm{NO}$ level cause inhibited $\mathrm{H}_{2} \mathrm{O}_{2}$ catabolism in mouse peritoneal macrophages. The increase in $\mathrm{NO}$ and $\mathrm{H}_{2} \mathrm{O}_{2}$ concentrations in vitiligo patients lead to an increase in oxidative stress that causes further injury in melanocytes.

Catalase responsible for converting $\mathrm{H}_{2} \mathrm{O}_{2}$ to water, and inhibited NO production, therefore, increase in the production of $\mathrm{NO}$ in cells may be due to low catalase activity ${ }^{41,42,9}$. In observed result highly increased NOS activity in vitiligo patients may occur because there is an increase in its cofactor tetrahydrobiopterin which was found at high levels in the epidermis ${ }^{43}$.

The increased in this cofactor may be resulting from either defective in de novo synthesis or recycling or regulation of tetrahydrobiopterin in vitiligo patients ${ }^{44}$, which lead increased in NOS activity and accumulation of $\mathrm{NO}$ in melanocytes.

NO might produce from NOS or others sources such as melanocytes cells or the extracellular environment ${ }^{45}$. This free radical is inherently reactive and mediates cellular toxicity by damaging critical metabolic enzymes and enter in reaction with superoxide anion $\left(\mathrm{O}_{2}-\cdot\right)$ to form an even more potent oxidant, peroxynitrite (ONOO- $)^{18}$ that may be caused serious damage to lipid, protein and DNA which also lead to destruction of melanocyte cell ${ }^{19,20}$.

\section{CONCLUSION}

In conclusion, we modified a simple method for assessments of nitric oxide synthase activity in the vitiligo and healthy individual that show high precision at optimum condition. Out of the result from the present study, one can conclude that vitiligo disease caused alterations in the activity of nitric oxide synthase and nitric oxide concentration in plasma samples at different degree. These results support the autocytoxic theory in explaining of vitiligo pathogenesis, and melanocytes cells destruction or dysregulation of melanogenesis could be mediated by free radical.

\section{ACKNOWLEDGMENT}

The authors are thankful to Dr. Hossam Ali and all the staff in the Baghdad teaching hospital/ Dermatology department. 


\section{REFERENCE}

1. Parsad, D.; Dogra, S.; Kanwar, A. J. Health and Qual. of life outcomes., 2003, 1, 58.

2. Daniel, B. S.; Wittal, R. Australas. J. Dermatol., 2015, 56, 85-92.

3. Alikhan, A.; Felsten, L. M.; Daly, M.; PetronicRosic, V. J. Am. Acad. Dermatol., 2011, 65, 473-491.

4. Ogg, G. S.; Rod Dunbar, P.; Romero, P.; Chen, J. L.; Cerundolo, V. J. Exp. Med., 1998, 188, 1203-1208.

5. Cucchi, M. L.; Frattini, P.; Santagostino, G.; Orecchia, G. Pigment cell Res., 2000, 13, 28-32.

6. Maresca, V.;Roccella, M.; Roccella, F.; Camera, E.; Del Porto, G.; Passi, S.; Grammatico, P.; Picardo, M. J. Invest. Dermatol., 1997, 109, 310-313.

7. Schallreuter, K. U. Skin Pharmacol. Appl. Skin Physiol., 1999, 12, 132-138.

8. Dell'Anna, M. L.; Maresca, V.; Briganti, S.; Camera, E.; Falchi, M.; Picardo, M. J. Invest. Dermatol., 2001, 117, 908-913.

9. Sravani, P. V.; Babu, N. K.; Gopal, K. V.; Rao, G. R.; Rao, A. R.; Moorthy, B.; Rao, T. R. Indian J. Dermatol. Venereol. Leprol., 2009, 75, 268-271.

10. Giovannelli, L.; Bellandi, S.; Pitozzi, V.; Fabbri, P.; Dolara, P.; Moretti, S. Mutat. Res., 2004, 556, 101-106.

11. Salem, M. M.; Shalbaf, M.; Gibbons, N. C.; Chavan, B.; Thornton, J. M.; Schallreuter, K. U. FASEB J., 2009, 23, 3790-3807.

12. Westerhof, W.; d'Ischia, M. Pigment Cell Res., 2007, 20, 345-359.

13. O'dell, T.J.; Hawkins, R. D.; Kandel, E. R.; Arancio, O. Proceedings of the National Academy of Sciences., 1991, 88, 11285-11289.

14. Förstermann, U.; Mülsch, A.; Böhme, E.; Busse, R. Circ. Res., 1986, 58, 531-538.

15. Gudi, T.; Hong, G. K.; Vaandrager, A. B.; Lohmann, S. M.; Pilz, R. B. FASEB J., 1999, 13, 2143-2152.

16. Liu, X. B.; Hill, P.; Haile, D. J. Blood Cells Mol. Dis., 2002, 29, 315-326.

17. Brüne, B.; Dimmeler, S.; y Vedia, L. M.; Lapetina, E. G. Life Sci., 1994, 54, 61-70.

18. Förstermann, U.; Sessa, W. C. Eur. Heart J.,
2011, 33, 829-837.

19. Lee, J. H.; Yang, E. S.; Park, J.-W. J. Biol. Chem., 2003, 278, 51360-51371.

20. Mikkelsen, R. B.; Wardman, P. Oncogene., 2003, 22, 5734-5754.

21. Forman, H. J.; Fukuto, J.; Torres, M. Signal transduction by reactive oxygen and nitrogen species: pathways and chemical principles: Springer; 2003.

22. Salter, M.; Knowles, R. G. Nitric oxide protocols. 1998, 61-65.

23. Bredt, D. S.; Snyder, S. H. Proc. Natl. Acad. Sci., 1989, 86, 9030-9033.

24. Cortas, N. K.; Wakid, N. W. Clin. Chem., 1990, 36, 1440-1443.

25. Bush, P. A.; Gonzalez, N. E.; Griscavage, J. M.; Ignarro, L. J. Biochem. Biophys. Res. Commun., 1992, 185, 960-966.

26. Haycock, J. W.; Rowe, S. J.; Cartledge, S.; Wyatt, A.; Ghanem, G.; Morandini, R.; Rennie, I. G.; MacNeil, S. J. Biol. Chem., 2000, 275, 15629-15636.

27. Koca, R.; Armutcu, F.; Altinyazar, H.; Gürel, A. Clin. Exp. Dermatol., 2004, 29, 406-409.

28. Vaccaro, M.; Irrera, N.; Cutroneo, G.; Rizzo, G.; Vaccaro, F.; Anastasi, G. P.; Borgia, F.; Cannavò, S. P.; Altavilla, D.; Squadrito, F. Int. J. Mol. Sci., 2017, 18, 2533.

29. Yildirim, M.; Baysal, V.; Inaloz, H. S.; Kesici, D.; Delibas, N. J. Dermatol., 2003, 30, 104-108.

30. Zhang, Y.; Li, C.; Li, K.; Liu, L.; Jian, Z.; Gao, T. PLoS One., 2011, 6, e27077.

31. Le Poole, I. C.; Van Den Wijngaard, R. M.; Westerhof, W.; Das, P. K. Am. J. Clin. Pathol., 1996, 148, 1219-1228.

32. Maresca, V.; Roccella, M.;Roccella, F.; Camera, E.; Del Porto, G.; Passi, S.; Grammatico, P.; Picardo, M. J. Invest. Dermatol., 1997, 109, 310-313.

33. Agrawal, D.; Shajil, E.; Marfatia, Y.; Begum, R. Pigment Cell Melanoma Res., 2004, 17, 289-294.

34. Singh, S.; Singh, U.; Pandey, S. Egyptian Dermatol Online J., 2011, 7, 1-7.

35. Ivanova, K.; Le Poole, I. C.; Gerzer, R.; 
Westerhof, W.; Das, P. K. The Journal of pathology., 1997, 183, 469-476.

36. Rocha, I. M.; Guillo, L. A. Arch. Dermatol. Res., 2001, 293, 245-248.

37. Bonfoco, E.; Leist, M.; Zhivotovsky, B.; Orrenius, S.; Lipton, S. A.; Nicotera, P. J. Neurochem., 1996, 67, 2484-2493.

38. Meßmer, U. K.; Brüne, B. Arch. Biochem. Biophys., 1996, 327, 1-10.

39. Boscá, L.; Hortelano, S. Cell. Signal., 1999, 11, 239-244.

40. Li, Y.; Severn, A.; Rogers, M. V.; Palmer, R. M.; Moncada, S.; Liew, F. Y. Eur. J. Immunol., 1992, 22, 441-446.

41. Maresca, V.; Flori, E.; Briganti, S.; Mastrofrancesco, A.; Fabbri, C.; Mileo, A. M.; Paggi, M. G.; Picardo, M. Pigment Cell
Melanoma Res., 2008, 21, 200-205.

42. Schallreuter, K. U.; Wood, J. M.; Berger, J. J. Invest. Dermatol., 1991, 97, 1081-1085.

43. Schallreuter, K. U.; Moore, J.; Wood, J. M.; Beazley, W. D.; Peters, E. M.; Marles, L. K.; Behrens-Williams, S. C.; Dummer, R.; Blau, N.; ThoÈny, B. J. Invest. Dermatol., 2001, 116, 167-174.

44. Schallreuter, K. U.; Moore, J.; Wood, J. M.; Beazley, W. D.; Gaze, D. C.; Tobin, D. J.; Marshall, H. S.; Panske, A.; Panzig, E.; Hibberts, N. A. J Investig Dermatol Symp Proc., 1999.

45. Hazneci, E.; Karabulut, A. B.; Öztürk, Ç.; Batçioglu, K.; Dogan, G.; Karaca, S.; Esrefoglu, M. Int. J. Dermatol., 2005, 44, 636-640. 